or Properties of Matter, he wrote rather caustically:

"Of the importance of turning a knowledge of chemistry to household purposes I have been long satisfied. The common herd of philosophers seem to write only for one another. The chemists have filled volumes on the composition of a thousand substances of no sort of importance to the purposes of life"

During the five years he spent in France-and in travelling widely in Europe-Jefferson served almost as a one-man bureau of information in keeping his American friends abreast of the progress of European science, sending home books and journals to Rittenhouse, Franklin and Rush and to the colleges of Yale, William and Mary, Harvard and Philadelphia. He returned in $\mathbf{1 7 8 9}$ more than ever determined to encourage scientific activity and to obtain proper recognition for American scientists. His own prestige, and his appointment as Secretary of State in Washington's first cabinet and later of course as Vice-President and finally as the third President of the United States, helped materially in raising the standing of science in his country and its significance to the community.

Jefferson also amassed the finest library of his time, which eventually became the nucleus of the Library of Congress, just as the library of George IIIhimself something of an amateur scientist-became the nucleus of the British Museum Library!

But despite George III and some of his ministers, relations between scientists in the colonies and those in the mother country were not altogether impaired, and the spirit of encouragement was renewed after the negotiation of peace with England in which Franklin had played the major role. Writing to Franklin in $1783 \mathrm{Sir}$ Joseph Banks, the greatest President the Royal Society had elected for many years, looked forward to the prospect of freer communications, and went on:

"My sincere congratulations on the return of peace, which in whatever form she is worshipped, bad peace or good peace, never fails to prove herself the Faithful nurse of Science."

\title{
Facsimile of the Peace Treaty
}

\section{AN ATTRACTIVE APPLICA'TION OF GOLD ELECTROFORMING}

No less important than the Declaration of Independence was the Peace Treaty signed at the York Hotel in Paris between England and the United States in September 1783. One unusual and attractive feature of the bicentennial celebrations is a facsimile of this treaty, printed on handmade paper similar to that of the original document, bound in leather, and with the eight corner pieces and the central plaque on the covers and the seals of the signatories-John Adams, Benjamin Franklin, John Jay and the English pleniopotentiary, Franklin's friend David Hartley-reproduced in high purity gold by electroforming from the originals. A modified sulphite bath was used, and all the gold ietms are hall-marked.

A limited number of copies of this collector's item will be produced later in the year and will be available from B.J.S. Electro-Plating Company Ltd, 348 Kilburn High Road, London NW6.

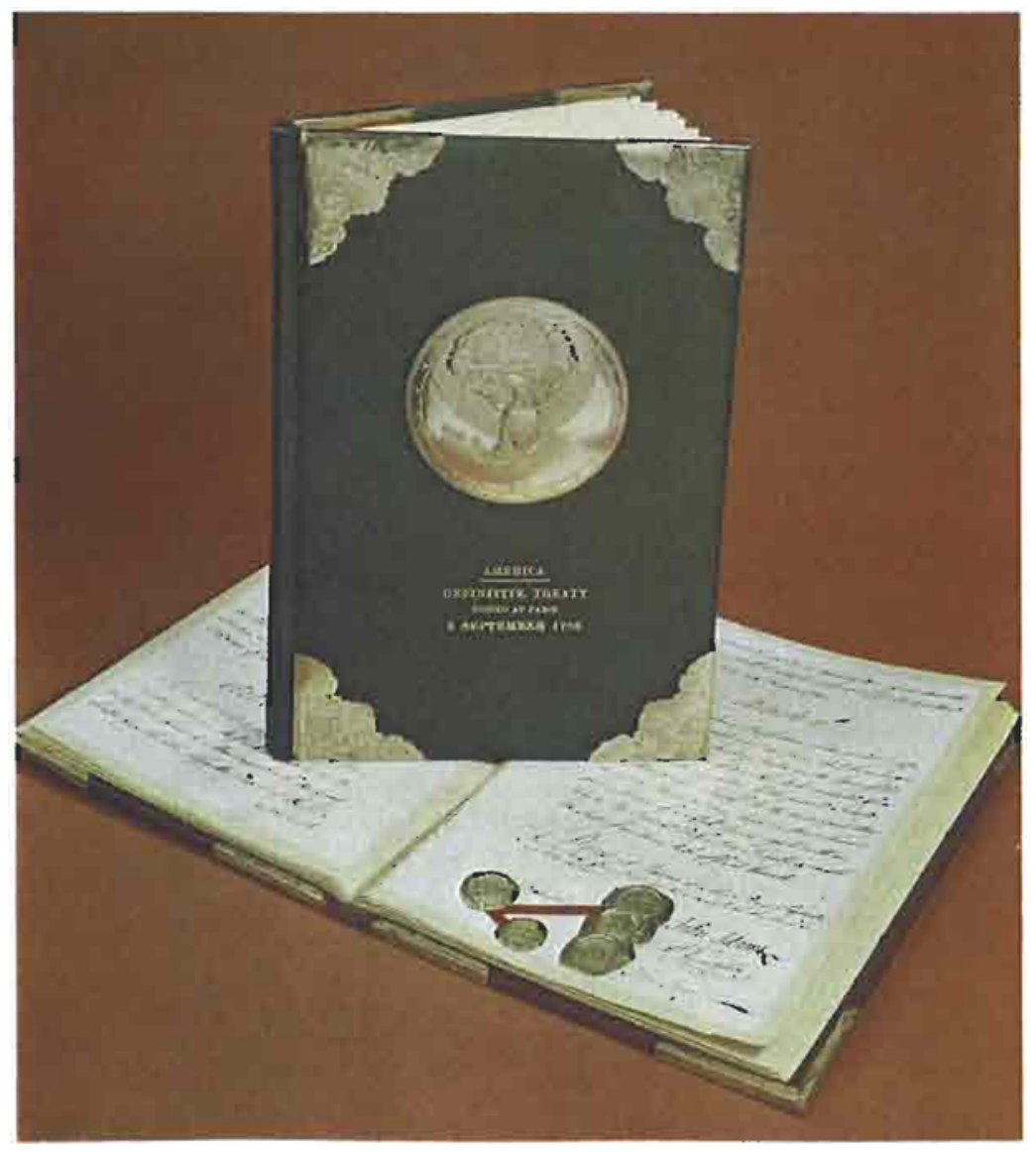

